\title{
BULGARIAN STUDENTS’ PERCEPTIONS OF ISSUES AND CHALLENGES IN PREPARING FOR THE ENGLISH LANGUAGE MATURITY EXAM
}

\author{
Irina Ivanova ${ }^{1}$, Gergana Gerova ${ }^{2}$
}

\begin{abstract}
The article looks into issues related to the maturity exam in English on the basis of a survey conducted with Bulgarian students who intended to sit the exam. The scope of investigation includes students' reasons for choosing the exam, their preparation, and the difficulties they experience in the language areas and skills it covers. The results helped to identify aspects of the exam, which make it students' preferred choice for a second obligatory school-leaving test. Respondents' selfevaluation in the skill and knowledge areas resulted in a comprehensive picture of test-takers' strengths and difficulties, and identified issues, which have to be taken into consideration by teachers and officials responsible for preparing the exam and evaluating its quality.
\end{abstract}

Key words: maturity exam in English, Bulgarian students, perceptions, challenges, language areas and skills

\section{Introduction}

The maturity exam in English as a foreign language is a kind of proficiency exam which Bulgarian students can choose to sit at the end of their 12-year school education. Aimed at testing overall language proficiency at the time of school leaving, the exam is supposed to measure both students' overall achievement over a period of language learning, and their readiness to use the language in real-life situations or for further studies or work. As a rule, in proficiency exams, students' global competence in the language is measured irrespective of their preparation in terms of courses and curricula, and covers all areas of language competence. In Bulgaria, the level of the test difficulty is estimated to match level B2 in the Common European Frame of Reference, and it takes into account the differences in the curricula followed by different types of schools. However, being only written, the maturity exam does not test students' speaking

1. Associate Prof., Ph.D., Department of English Studies, Shumen University, Bulgaria, e-mail: irina.ivanova@shu.bg, ORCID: 0000-0002-0216-7061

2. Ph.D, Department of German Studies, Shumen University, Bulgaria, Faculty of Humanities, e-mail: g.gerova@shu.bg, ORCID: 0000-0003-1934-3882 
skills, a fact which raises serious concerns about its validity in assessing overall language ability.

The exam consists of four components: listening, reading, use of English and writing. The first three components include 60 display items with a single or limited number of correct answers and a writing task in which students can choose between two essay topics. The total number of points is 100,30 of which are assigned for the writing task, and 70 - for the other components. The time for the exam is 4 hours (http://www.zamatura.eu/page/matura-chujd-ezik-programa).

In addition to measuring students' ability or competence in the foreign language, the maturity exam also provides feedback to both educational policy makers and teachers. The significant percentage of students who choose English for their second maturity exam is growing progressively, which might be an indicator for the quality of foreign instruction at school. According to the Assessment Centre for pre-school and school education data, in the last three years there has been a rise in the number of test-takers, as in 2017 there were 11460 candidates, in 2018 - 13 522, in 2019 - 14 412. In 2020 the maturity exam in English was students' first choice for the second obligatory exam, with 11884 out of 37116 students. Compared to other foreign languages, English is by far the first preferred language (the exam in German was chosen by 994 students, French - by 373, Russian - 321, and Spanish - by 319) (https://www.segabg.com/ hot/category-education/mon-publikuva-vuprosite-i-otgovorite-na-maturata).

\section{Theoretical background}

The fact that language ability is a "complicated, multifaceted construct, consisting of many interdependent or independent subskills, each of which can be operationalised in many different ways" (Schoonen, 2011, p. 702), makes its assessment rather complex. Defined as "the ability to perform language tasks in real life and real time, that is, the ability to convey or understand a content message through the medium of spoken or written language" (ibid.), it entails the successful activation of a range of cognitive processes through a selection of relevant tasks. The main issue debated by researchers in relation to measuring language ability is whether it should be viewed as a monolithic construct, or as consisting of separate constituent abilities with a different weight in assessing the whole (Bachman, 2007,2010; Chalhoub-Deville, 2003; Chapelle, 1998; McNamara, 1996). Another challenge lies in discriminating between students' content knowledge and their language ability, especially in assessing their productive performance in writing and speaking. In addition, there are factors such as handwriting in writing and pronunciation in speaking, which might affect the assessment of students' overall performance. 
In measuring language ability, researchers' aim is to assess learners' grammatical and lexical knowledge, usually measured in what is known as Use-of-English section of proficiency exams, now included in the reading section of the Cambridge FCE, CAE and CPE exams, and integrated within the four skills in other exams, such as IELTS and TOEFL.

In assessing learners' skills development, the macro skills are broken down into microskills or micro processes, which have to be executed for the successful completion of the respective macro-skill tasks (Cutler \& Clifton, 1999). The time limit which is set for each skills section requires a good level of automaticity, which guarantees the easy retrieval and use of the needed language (Harrington, 2006).

O'Sullivan (2011) emphasizes the fact that tests developed for use in a local context (such as the maturity exam) should be subject to the same requirements of consistency and accuracy as their international counterparts, which leads to diminishing the difference between local and international tests. Therefore, the maturity exam presents a combination of tasks with a narrow focus on skills, subskills and processes, such as multiple-choice listening and reading, gap filling, sentence completion and transformation, as well as text creation. The information about students' language ability is obtained by calculating the number of correct answers and by assigning points to their written text by means of analytic rating scales also known as criteria bands. This combination of approaches to testing receptive and productive skills is thought to be sufficient in providing information about students' language ability. However, in testing language ability, researchers should take into consideration the effect of students' typical behavior, which, according to Cronbach (1961) may not reflect their highest possible performance level.

The importance of test tasks is conceptualized in a framework of three key aspects which test developers take into consideration: the stimulus material that is given to students, the instructions and the constraints they impose, and the way test scores are interpreted (Alderson, 2000; Bachman \& Palmer, 1996). In the maturity exam, the stimulus material which is available to test takers and is used for doing the respective tasks has a different form depending on the task. It could be a recorded material for listening or a reading text, which has to be processed top-down and bottom-up in order to elicit the gist or specific information. In the Use-of-English tasks it is the gapped text or sentences, which have to be transformed or completed, and in the writing task it is the instruction for creating a certain type of text. Criteria for test validity should ensure that tasks test what they claim to test and nothing else, e.g. a reading comprehension task should not be complicated by choosing texts on topics which are unfamiliar to students, or which are full of specialized vocabulary from certain areas of knowledge. Similar caution is applied in choosing the stimulus structures in the 
Use-of-English part, where the required transformations might test particularly difficult or infrequent structures, usually studied only marginally or superficially in class.

In order to ensure maximum performance, the instructions to the tasks should be clear and straightforward, and should not deviate from the ones given to students throughout their learning and test preparation. Students need to know in advance how many times they will hear the texts and whether they are allowed to take notes during the listening (Buck, 2001; Sherman, 1997). They need to be able to activate and integrate the cognitive and metacognitive strategies acquired previously depending on the reading task (Gerova, 2019). In the writing task, students need to know the purpose of writing a particular type of text and the target audience expectations.

The evaluation of students' performance in the exam results in an estimation of their language proficiency level. Their receptive ability is assessed through the sum of the correct answers in the listening and reading tasks (Berent et al., 2008; Webb, 2008). This 'objective' scoring is combined with the results of the Useof-English tasks constructed responses, and the students' written texts, which are assessed by means of a criteria band. The scoring of students' production can be additionally complicated by spelling mistakes (Messick, 1989).

In order to reduce subjectivity, the rating criteria in writing should be dominated by the requirement for the relevance of the writer's response to the task (Fulcher, 2003; Weigle, 2002). If the relations between task instructions and scoring criteria are not taken into consideration, the assessment of language ability becomes problematic, as it "does not reflect the underlying cognitive processes and language skills" (Schoonen, 2011, p. 711).

The idea of dividing the areas of language teaching and testing into four skills originally followed the model of the native speaker's competency. Characteristic of pre-communicative methodology, and associated with isolated pattern practice, error avoidance, and native-speaker model, this view contrasts markedly with teaching language as a means of communication (Hinkel, 2010). Most modern communicative and post-communicative approaches advocate an integration of the four skills in both teaching and testing as much as possible, while at the same time building learners' cultural awareness and the qualities they need to deal successfully with people from other cultures. In practice, testing the four skills involves the activation of learners' experiential, cultural, textual, linguistic and pragmatic knowledge. Students' performance in the exam is assessed on the basis of established criteria (cf. criterion vs norm-based assessment); it is summative and external. However, students' preparation for the exam should reflect the principles of ongoing, formative and dynamic assessment, which requires an active teaching approach based on understanding 
learners' needs, adapting teaching materials and providing immediate feedback (see Hidri, 2020).

The testing of learners' receptive performance in the maturity exam is carried out by means of different listening and reading tasks. Understanding oral or written discourse involves much more than just knowledge of the language (Harmer, 2001), and without activating pre-existent knowledge of the world (both universal and culture-specific) it is very difficult or even impossible for learners to correctly interpret the received message. In the listening tasks, test takers have to process speech characterized by phonological peculiarities, such as accent and pronunciation, while at the same time attending to the meaning contained in the input by applying segmentation procedures which are different from the ones used in their native language (Cutler, 2001; Vandergrift, 2011). Listening is characterized by simultaneous top-down and bottom-up processing of information, which helps learners to create a mental representation of what they have heard (Hulstijn, 2003). The lack of automaticity typical of L1 listening, and the limited L2 proficiency might make listeners apply conscious control, which in turn limits or prevents their comprehension. However, if learners are trained to use compensatory strategies and contextual cues, their listening comprehension can improve, especially if they are aware of this type of metacognitive knowledge. Research shows that metacognition, and the combined use of cognitive and metacognitive strategies can have a positive impact on learners' achievement, motivation and self-efficacy (Zimmerman \& Schunk, 2001; Vandergrift, 2005), and that increasing students' awareness of the role of metacognition can positively benefit their performance. The activation of prior knowledge in top-down listening can be another source of difficulty, especially if students over-rely on it in choosing the correct answer, instead of attending to input information.

Understanding learners' difficulties in reading requires a consideration of some distinctive features of written discourse, such as its greater lexical and grammatical complexity in comparison to listening, and conformity to the conventions of formality. Another factor, which affects reading performance, is the effect of students' fluency and automaticity in first language reading (Birch, 2006), which can only be developed with consistent practice. In Bulgaria, a study by the Center for monitoring and evaluating the quality of school education and 'Together in Class' Foundation found out that students'interest in reading is low. According to their data, over $60 \%$ of children surveyed read only if they have to. About $40 \%$ have difficulty reading a book to the end, and $32 \%$ believe that reading is a waste of time. In general, it is children from families with well educated parents who have a greater interest in reading, and school education does not always manage to compensate for these deficiencies in the family environment (http://btvnovinite.bg/article/bulgaria/obshtestvo/dvama-ot-trima-uchenicichetat-samo-ako-trjabva.html). A report by the European Commission for 
Education, Culture and Youth reported that Bulgarian students up to 15 years of age have the worst reading skills compared with their peers in other countries of the European Union (http://www.hermesbg.org/tr/nova-biblioteka/book-30/995agonizira-li-obrazovatelnata-ni-sistema.html). However, research indicates that proficient readers in L1 are not necessarily as good in L2 reading, and it is not clear whether their difficulties result from a reading or a language problem. Alderson (1984) hypothesized that poor reading is due to either application of inappropriate syntactic, semantic, and discourse comprehension strategies which do not work in a foreign language, or inadequate knowledge of the target language. On the other hand, according to Krashen (1993, p. 84), "students who read frequently acquire, involuntarily and without conscious effort, nearly all of the so-called language skills". Researchers agree that readers do not decode the text in sequential order, but instead "attack the text with expectations of meaning developed before and during the process, taking in whole chunks of text, ... to confirm and extend their expectations (Eskey, 2005, p. 565). Then this new information is mapped against the previous knowledge or schemata they bring into the process in order to construct the meaning of the text that is being read. Successful L2 readers have to have extensive vocabulary which they can recognize automatically (Stanovich, 1991) or safely guess from context, although extensive guessing might be linked to misinterpretation of meaning (Bernhardt, 1991). Knowledge of grammar is also essential for interpreting the meaning correctly, therefore the texts in exam formats are syntactically simplified to enhance language comprehension. Understanding text structure is another important factor in reading, especially in answering questions related to different parts of the texts. To sum up, there are a lot of factors which determine students' success or failure in reading, which means that the assessment of reading requires multiple measures and taking into account a range of learner variables and text features.

Use of English is the section in the exam in which students' success is most dependent on their previous preparation in term of conscious study of grammar and vocabulary. In the maturity exam, the types of tasks or test elicitation techniques (Ur, 1996) involve a cloze test, with four options for each gap, sentence completion with the same number of options for the gaps, and sentence transformations. The cloze in the exam is usually adapted to test specific aspects of vocabulary and grammar, such as collocation, lexical phrases, multi-part verbs, tenses, substitution, discourse markers, etc. The latter two are usually tested in short pieces of discourse, while the first ones can be tested in the minimal context of single sentences. Sentence transformations test students' knowledge of particular grammar structures, however, according to Ur (1996), they are not proper tests of grammar, as testees may perform on them well without knowing the meaning of the target structures or how to use them in context. The teaching and testing of grammar and vocabulary have undergone 
an important change from a manipulation of the form, to a focus on meaning and use.

Recent research on developing L2 writing has focused on the organizational and ideational structure of L2 discourse and the morphosyntactic and lexical characteristics of L2 text (Hinkel, 2011). The same aspects of written discourse have been targeted in writing tests, in which students' achievement is measured with the help of assessment bands which are based on a number of criteria, aimed at measuring students' macro and micro-skills of writing. Frequently, underachievement in writing is seen as resulting from differences between L1 and L2 discourse patterns and norms, and discourse paradigms which are "principally, strategically, and globally different from those found in L1 writing" (Hinkel, 2011, p. 528). Therefore, being good at writing in one's L1 does not mean being good at L2 writing. L2 writers tend to have problems with organizing and structuring their ideas; they rely more on unsubstantiated personal opinion or judgment than on evidence; they disregard audience or assume that their readers share the same background knowledge, etc., and even at an advanced level, have a severely limited lexical and syntactic repertoire compared to native speakers (for a detailed list of issues see Hinkel 2011, pp. 527-530). For these reasons, preparing students for the exam should include tasks which teach students how to generate and organize ideas, observe L2 discourse conventions, consider target audience, plan, draft, review and correct mistakes.

\section{The study: Method and participants}

Thestudy is based on a questionnaire which consists of items grouped into several parts. The parts reflect different aspects of students' preparation for the maturity exam in English and the perceived difficulties associated with it. The survey contained the following sections: personal information, reasons for choosing this maturity exam, aspects that might cause difficulties, students' perceived evaluation of their competence in the four skills, followed by a detailed reflection on the challenges presented by each section in the exam. The participants had to examine the statements in each section, and indicate the extent to which they agree with them, using a five-point Likert-scale from (1) Don't agree to (5) Strongly agree. Each section allows the option of writing a commentary in addition to the suggested ones.

The aim of the survey was to receive a comprehensive picture of the maturity exam in English from the perspective of the students who prepare for the exam. Students' perceptions of the challenges in test taking, and the awareness of their own strengths and weaknesses in the language are of key importance for informing both test makers and teachers, and improving the quality of teaching and exam preparation. 
The survey was created as a Google forms document and sent by class teachers to students who opted for the maturity exam in English at the end of 2019/2020 school year. In Shumen and the region, 73 out of the203 students who registered for the exam volunteered to take part in the survey, which is approximately one third of the total number of graduates. All participants were 12th graders from the four largest schools in Shumen - the Language School, the School of Mathematics and Science, the School of Humanities and the School of Arts.

By the time of completing the survey, 56,2\% of the participants were 19 years old and $43,8 \%$ were 18 (some students started school a year earlier than their classmates). $60,3 \%$ of the respondents were female as opposed to $39,7 \%$ male, which might reflect the male - female ratio of students, but might also mean that girls were more willing to respond to the survey. By the time of responding, 57,5\% participants had been studying English for more than 11 years, while $42,5 \%$ had been studying it for more than 4 years. This might indicate that the number of years spent on studying the language is not the key factor in deciding to sit the exam. It might also mean though that an early start alone is not necessarily a precondition for reaching the required proficiency level for the exam.

\section{Data analysis, results and discussion}

The first section of the survey inquires into students' perceived reasons for choosing to sit the maturity exam in English (Table 1) and the people who they believe influenced their choice.

Table 1. Students' reasons for choosing to sit the maturity exam in English in \%

\begin{tabular}{|l|l|l|l|l|l|}
\hline $\begin{array}{l}\text { I decided to take the } \\
\text { maturity exam in English } \\
\text { because... }\end{array}$ & $\begin{array}{l}\text { Don't } \\
\text { agree }\end{array}$ & $\begin{array}{l}\text { Somewhat } \\
\text { agree }\end{array}$ & $\begin{array}{l}\text { Neither } \\
\text { agree nor } \\
\text { disagree }\end{array}$ & Agree & $\begin{array}{l}\text { Strongly } \\
\text { agree }\end{array}$ \\
\hline $\begin{array}{l}\text { It is easier than the other sub- } \\
\text { ject exams }\end{array}$ & 13,7 & 6,8 & 26 & 34,2 & 19,02 \\
\hline $\begin{array}{l}\text { English is one of my best } \\
\text { subjects }\end{array}$ & 1,4 & 2,8 & 15,3 & 25 & 55,6 \\
\hline $\begin{array}{l}\text { I am familiar with the format } \\
\text { of the exam }\end{array}$ & 1,4 & 11 & 11 & 39,7 & 37 \\
\hline $\begin{array}{l}\text { I have practised doing simi- } \\
\text { lar tasks }\end{array}$ & 1,4 & 8,2 & 16,4 & 35,6 & 38,4 \\
\hline $\begin{array}{l}\text { I am familiar with the assess- } \\
\text { ment criteria }\end{array}$ & 4,1 & 12,3 & 26 & 38,4 & 19,2 \\
\hline I want to test my English & 5,5 & 4,1 & 13,7 & 32,9 & 43,8 \\
\hline I study English intensively & 2,7 & 8,2 & 20,5 & 37 & 31,5 \\
\hline I want to study abroad & 28,8 & 9,6 & 21,9 & 15,1 & 24,7 \\
\hline
\end{tabular}




\begin{tabular}{|l|l|l|l|l|l|}
\hline $\begin{array}{l}\text { I decided to take the } \\
\text { maturity exam in English } \\
\text { because... }\end{array}$ & $\begin{array}{l}\text { Don't } \\
\text { agree }\end{array}$ & $\begin{array}{l}\text { Somewhat } \\
\text { agree }\end{array}$ & $\begin{array}{l}\text { Neither } \\
\text { agree nor } \\
\text { disagree }\end{array}$ & Agree & $\begin{array}{l}\text { Strongly } \\
\text { agree }\end{array}$ \\
\hline $\begin{array}{l}\text { I want to study English at } \\
\text { university }\end{array}$ & 19,2 & 13,7 & 32,9 & 11 & 23,3 \\
\hline Other (please specify below)* & & & & & \\
\hline
\end{tabular}

More than half of the respondents think that the maturity exam in English is easier than the other subject exams $(54,4 \%)$. Moreover, the majority $(80,6 \%)$ think that English language is one of their best subjects at school. Among the other reasons for choosing the exam are: familiarity with the exam format $76,7 \%$; doing similar tasks $-74 \%$; and familiarity with assessment criteria $57,6 \%$. Only about $19 \%$ of students strongly agree that they are familiar with criteria, which suggests that students do not tend to rely on self-evaluation, but prefer to be assessed by an external authority (see Ivanova 2020). It might also be due to the fact that exam preparation in school does not involve discussion and practice of using assessment criteria by students. $76,7 \%$ of survey takers chose to sit the exam to test their level of English, which might mean that they see the exam as a free-of-charge way of testing their proficiency level before attempting a higher stake paid exam, such as IELTS. $68,5 \%$ of the students see intensive study of English as a reason to take this maturity exam, whereas $39,8 \%$ chose it because they want to study abroad. Perhaps not surprisingly, in the context of the coronavirus lockdown, studying abroad as a reason for sitting the exam triggered polarized opinions: $28,8 \%$ said they do not intend to study abroad, as opposed to $24,7 \%$ who strongly agreed to this reason. Seven participants added other reasons, the main of which was that they like the language.

For $97,2 \%$ of the respondentschoosing the exam in English was their personal decision. The rest were encouraged by their teachers, or followed their parents' advice. Some students' choice $(6,9 \%)$ was influenced by other students who took the exam, but not by their classmates, which indicates that by the time students graduate they can make their own decisions and are less dependent on outer influences, including peer pressure.

The next part of the survey looked into aspects of the exam which might create problems for students, such as understanding instructions, doing the test within the time limit, coping with stress, and maintaining focus and concentration. Affective variables, such as anxiety, can have a strong negative effect on students' performance, particularly in the context of evaluation (Mendelsohn, 1994). Motivation and self-efficacy, on the other hand, are thought to be beneficial to learners' performance. Students' answers are given in table 2 below: 
Table 2. Aspects which might create problems in the exam in \%

\begin{tabular}{|l|l|l|l|l|l|}
\hline $\begin{array}{l}\text { When doing similar tests, } \\
\text { I have difficulties in }\end{array}$ & $\begin{array}{l}\text { Don't } \\
\text { agree }\end{array}$ & $\begin{array}{l}\text { Somewhat } \\
\text { agree }\end{array}$ & $\begin{array}{l}\text { Neither } \\
\text { agree nor } \\
\text { disagree }\end{array}$ & Agree & $\begin{array}{l}\text { Strongly } \\
\text { agree }\end{array}$ \\
\hline Understanding instructions & 46,6 & 32,9 & 15,1 & 1,4 & 4,1 \\
\hline Finishing within time limit & 23,3 & 35,6 & 28,8 & 6,8 & 5,5 \\
\hline Coping with stress & 17,8 & 23,3 & 27,4 & 19,2 & 12,3 \\
\hline $\begin{array}{l}\text { Maintaining focus and con- } \\
\text { centration }\end{array}$ & 9,6 & 31,5 & 30,1 & 23,3 & 5,5 \\
\hline
\end{tabular}

Figures show that most students do not have problems understanding instructions. However, it is not clear if they refer to similar tests or to previous maturity exam papers, which they access online online, as the latter have regularly been criticized by both teachers and students for having unclear instructions, especially for the listening tasks. In our opinion, the instructions for the listening part are still highly ambiguous. Thus, during the first listening, students are not allowed to take notes, which probably means that they are not allowed to circle the correct answer when they hear it - a requirement which contradicts all known practices in testing listening skills used in exams. Students are instructed to wait till the end of the listening and then transfer the answers to the answer sheet, after which they can hear the text again and check for 1 minute if their answers are correct. There are at least three things that seem highly problematic: first, trying to remember the correct answers without marking them creates a huge overload of the short term memory; second, three minutes for choosing the correct answers without listening to the text might cause confusion, as students will try to compensate for the missed information or add their own interpretation in the lack of input. In this context, the second listening for checking the answers might only add to the confusion, as there is not enough time for more corrections.

Doing the test within the time limit does not seem to be a challenge for $23,3 \%$ of the respondents, while the rest admit that it affects their performance, and $12,3 \%$ say they have difficulties completing the task within the given time. While time management could be improved with practice, it might also be indicative of problems related to students' proficiency in the language.

Coping with exam-related stress does not seem to be an issue for the students, as most of them were not sure about it, and their answers are more evenly distributed among the response options. An aspect which usually causes more problems is maintaining focus and concentration, usually an issue with the digital-native generation and their multitasking in working and studying. However, there is a very slight difference in percentage between those who consider it a difficulty $30,1 \%$ and those who do not see it as a problem. 
In addition to these potential areas of difficulty, students were asked to selfassess the knowledge and skill tested in the exam. Practising self-assessment has an important role in improving students' cognitive and meta-cognitive abilities, and helps to correct 'inadequate' self-assessment and ideas about the nature of the study process (see Markova, 2020).

Although speaking is not part of the maturity exam, we included it in the survey as an essential part of the overall language ability. The results are presented in Fig.1 below:

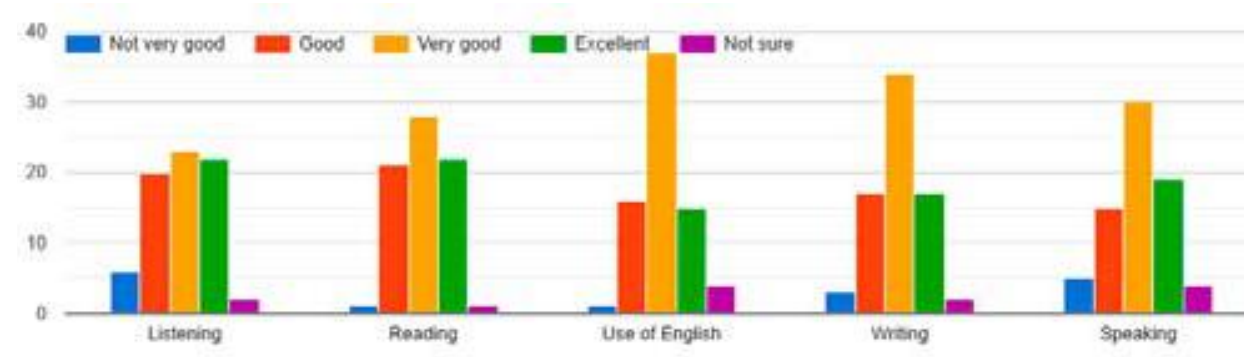

Fig. 1. Students' self-assessment on exam components and speaking

The prevailing option, chosen in all language areas is very good, and the area in which the largest number of students assess their abilities as very good is Use of English, followed by writing and speaking. A possible reason might be that grammar is viewed as an important and difficult part of the language, and students devote a considerable amount of time and effort to learn and practice grammar rules and structures in class or as homework assignments.

In writing, the number of students who consider themselves good or excellent is equal. The students who admit that they are not good at it are more than those who are not sure about it.

In the area of speaking, 30 students rate their abilities as very good. The number of students who do not think they are good is slightly higher compared to the previous two language areas. Speaking and Use of English are the areas in which the largest numbers of students are not sure about their abilities. As for speaking, this is probably due to the fact that it is hardly ever practiced in reallife situations where students can get feedback from real interlocutors, not the teacher, and in classes with a large number of students there is not enough time for each student to speak. What is more, since this skill is not tested in the exam, teachers might not give it due attention. The possible explanation for students' uncertainty in the Use of English section lies in the fact that it is almost always corrected by the teachers, often without detailed feedback. 
The margin between very good, good and excellent is smaller in reading, and the smallest in listening. Reading is the skill with the smallest number of students who arenot sure about their abilities or do not think they are good at reading. While reading and listening are the areas in which most students consider themselves excellent, somewhat surprisingly, the number of students who admit to not being good is the highest, compared to all the other exam areas.

The final section of the survey requires the students to give their opinion on issues which might cause difficulties in each of the exam areas.

The survey results provide evidence that learners' performance in listening is influenced by a combination of interacting cognitive, metacognitive and affective factors, which come into play in the process of exam listening. The percentage of respondents who practise extensive listening is significantly high $-64,4 \%$ strongly agree, and $23,3 \%$ agree that they listen to English a lot outside class. This might suggest that listening for pleasure could lead to a gradual improvement in the skill, a conjecture which contradicts students' selfassessment in the previous section of the survey (see table 3 ).

Table 3. Students' perceived difficulties in listening in \%

\begin{tabular}{|l|l|l|l|l|l|}
\hline Listening & $\begin{array}{l}\text { Don't } \\
\text { agree }\end{array}$ & $\begin{array}{l}\text { Somewhat } \\
\text { agree }\end{array}$ & $\begin{array}{l}\text { Neither } \\
\text { agree nor } \\
\text { disagree }\end{array}$ & Agree & $\begin{array}{l}\text { Strongly } \\
\text { agree }\end{array}$ \\
\hline $\begin{array}{l}\text { I listen to English a lot out- } \\
\text { side class }\end{array}$ & 1,4 & 2,7 & 8,2 & 23,3 & 64,4 \\
\hline $\begin{array}{l}\text { I can't keep up with the } \\
\text { speaker }\end{array}$ & 37 & 32,9 & 27,4 & 1,4 & 1,4 \\
\hline $\begin{array}{l}\text { I lose concentration after the } \\
\text { first listening }\end{array}$ & 46,6 & 26 & 15,1 & 5,5 & 6,8 \\
\hline $\begin{array}{l}\text { I find it difficult to understand } \\
\text { the main ideas in the text }\end{array}$ & 43,8 & 28,8 & 26 & 1,4 & 0 \\
\hline $\begin{array}{l}\text { I find it difficult to understand } \\
\text { details in the text }\end{array}$ & 20,5 & 34,2 & 30,1 & 12,3 & 2,7 \\
\hline $\begin{array}{l}\text { I need to take notes and mark } \\
\text { the correct answers while lis- } \\
\text { tening }\end{array}$ & 15,1 & 6,8 & 26 & 24,7 & 27,4 \\
\hline $\begin{array}{l}\text { I can't remember long bits of } \\
\text { information when I listen }\end{array}$ & 23,3 & 19,2 & 23,3 & 26 & 8,2 \\
\hline $\begin{array}{l}\text { I need to hear the exact words, } \\
\text { not paraphrased information }\end{array}$ & 30,1 & 21,9 & 28,8 & 6,8 & 12,3 \\
\hline $\begin{array}{l}\text { The option "no information in } \\
\text { the text" makes the task diffi- } \\
\text { cult and confusing }\end{array}$ & 12,3 & 15,1 & 17,8 & 24,7 & 30,1 \\
\hline Other (please specify)* & & & & & \\
\hline
\end{tabular}


The majority of the participants $(27,4 \%)$ share that they need to take notes and mark the correct answers while listening, although, as discussed above, they are not allowed to do it. The vast majority of students do not have difficulties in keeping up with the speed of delivery in the recordings, do not lose concentration and it is not a problem for them to get the gist of the listening text. Understanding paraphrased information in gap-filling or question answering does not seem to pose difficulties either, which means that the listening texts are at the right level of difficulty. However, $26 \%$ of students cannot retain long stretches of information in their short term memory, and about $30 \%$ are confused by the option "no information in the text". One of the students shared that she cannot clearly hear what the speaker says, which can sometimes be a problem for other students as well, due to external factors such as echo in the classroom or bad quality recordings. One way of improving students' performance is an explicit interconnected strategy instruction (Graham \& Macaro, 2008; Vandergrift, 2003), using a task-based pedagogical cycle which reflects real-life listening.

The results for the other receptive skill - reading, reveal a similarity in students' perceived difficulties and in the self-assessing of their abilities (see table 4 below):

Table 4. Students' perceived difficulties in reading in \%

\begin{tabular}{|l|l|l|l|l|l|}
\hline Reading & $\begin{array}{l}\text { Don't } \\
\text { agree }\end{array}$ & $\begin{array}{l}\text { Somewhat } \\
\text { agree }\end{array}$ & $\begin{array}{l}\text { Neither } \\
\text { agree nor } \\
\text { disagree }\end{array}$ & Agree & $\begin{array}{l}\text { Strongly } \\
\text { agree }\end{array}$ \\
\hline $\begin{array}{l}\text { I read in English outside } \\
\text { class }\end{array}$ & 0 & 2,7 & 6,8 & 32,9 & 57,5 \\
\hline $\begin{array}{l}\text { I don't like reading difficult } \\
\text { texts }\end{array}$ & 17,8 & 19,2 & 32,9 & 16,4 & 13,7 \\
\hline $\begin{array}{l}\text { I always read the whole text } \\
\text { quickly first }\end{array}$ & 16,4 & 21,9 & 20,5 & 19,2 & 21,9 \\
\hline $\begin{array}{l}\text { I try to understand all the un- } \\
\text { known words when I read }\end{array}$ & 6,8 & 17,8 & 19,2 & 32,9 & 23,3 \\
\hline $\begin{array}{l}\text { The time for reading is not } \\
\text { enough }\end{array}$ & 15,1 & 23,3 & 45,2 & 5,5 & 11 \\
\hline $\begin{array}{l}\text { I understand all the words } \\
\text { and still can't find the cor- } \\
\text { rect answer }\end{array}$ & 31,5 & 34,2 & 23,3 & 8,2 & 2,7 \\
\hline $\begin{array}{l}\text { It's more difficult when I } \\
\text { don't know much about the } \\
\text { topic }\end{array}$ & 34,2 & 23,3 & 32,9 & 8,2 & 1,4 \\
\hline $\begin{array}{l}\text { When checking, I often don't } \\
\text { understand why this is the } \\
\text { correct answer }\end{array}$ & 26 & 13,7 & 12,3 & 21,9 & 26 \\
\hline $\begin{array}{l}\text { The option “no information } \\
\text { in the text" makes the task } \\
\text { difficult }\end{array}$ & 21,9 & 11 & 37 & 23,3 & 6,1 \\
\hline Other (please specify)* & & & & & \\
\hline
\end{tabular}


The vast majority of students read extensively outside class, but a lot of them feel uncertain $(32,9 \%)$ whether they like reading difficult texts, while about $30 \%$ admit their aversion to it. This might mean that the amount of reading they do depends on the language difficulty of the texts read at school or at home. In the two extremes with equal percentages are those who always read the whole text quickly first and those who sometimes do it. This is indicative of the lack of appropriate strategy training at school, and of students' lack of awareness of what they actually do in reading tasks. A total of 56,2\% agree or strongly agree that they try to understand all the unknown words when they read, which strengthens the arguments of insufficient understanding of the nature of reading and poor instruction. The majority of students $(45,2 \%)$ are not sure about their time management, and are largely undecided about the importance of previous knowledge of the topic (37\%). For most of them reading is linked to deciphering the meaning of individual words and only about $11 \%$ agree that meaning making goes beyond understanding the words in a text. While with regard to listening, most students $(54,8 \%)$ agree that a third option complicates the decision, they were not sure about it in reading. To quote a student, "the main problem with the option 'no information in the text' is that there is a thin line between what is stated in the text and what is in the question. What is more, the exam is done (prepared) by Bulgarians who think like Bulgarians (obviously) but use texts written by British/ Americans so there is often misunderstanding."

There is a noticeable contrast between students' assessment of writing and reading, taking into account that they declare they read a lot outside class and yet they consider their reading abilities not as good as their writing. Presumably, they hardly write as much as they read outside class, which probably creates a false confidence of being better at writing than reading, as writing needs far more practice, feedback, and self-assessment against criteria, while reading, once mastered, is a lifelong, stable and individually sustainable skill.

The analysis of students' answers about Use of English shows that the majority of them find it challenging to decide on the nature of difficulties they face in this section, as they selected the neutral option for more than half of the questions (see table 3).

Table 5. Students' perceived difficulties in Use of English in \%

\begin{tabular}{|l|l|l|l|l|l|}
\hline Use of English & $\begin{array}{l}\text { Don't } \\
\text { agree }\end{array}$ & $\begin{array}{l}\text { Somewhat } \\
\text { agree }\end{array}$ & $\begin{array}{l}\text { Neither } \\
\text { agree nor } \\
\text { disagree }\end{array}$ & Agree & $\begin{array}{l}\text { Strongly } \\
\text { agree }\end{array}$ \\
\hline $\begin{array}{l}\text { I need to know the mean- } \\
\text { ing of all options to decide } \\
\text { which is correct }\end{array}$ & 9,6 & 21,9 & 21,9 & 28,8 & 17,8 \\
\hline $\begin{array}{l}\text { I do it quickly - the answer } \\
\text { just comes to me }\end{array}$ & 6,8 & 12,3 & 30,1 & 26 & 24,7 \\
\hline
\end{tabular}




\begin{tabular}{|l|l|l|l|l|l|}
\hline Use of English & $\begin{array}{l}\text { Don't } \\
\text { agree }\end{array}$ & $\begin{array}{l}\text { Somewhat } \\
\text { agree }\end{array}$ & $\begin{array}{l}\text { Neither } \\
\text { agree nor } \\
\text { disagree }\end{array}$ & Agree & $\begin{array}{l}\text { Strongly } \\
\text { agree }\end{array}$ \\
\hline $\begin{array}{l}\text { Phrasal verbs are difficult } \\
\text { for me }\end{array}$ & 13,7 & 23,3 & 31,5 & 17,8 & 13,7 \\
\hline $\begin{array}{l}\text { I know the synonyms but } \\
\text { don't know which to choose }\end{array}$ & 23,3 & 21,9 & 31,5 & 19,2 & 4,1 \\
\hline $\begin{array}{l}\text { I read the gapped text first } \\
\text { and then do the task }\end{array}$ & 20,5 & 12,3 & 31,5 & 21,9 & 13,7 \\
\hline $\begin{array}{l}\text { Sentence transformation is } \\
\text { the most difficult part }\end{array}$ & 32,9 & 19,2 & 16,4 & 17,8 & 13,7 \\
\hline $\begin{array}{l}\text { Studying grammar rules and } \\
\text { vocabulary is essential }\end{array}$ & 4,1 & 5,5 & 32,9 & 26 & 31,5 \\
\hline $\begin{array}{l}\text { Reading and listening to } \\
\text { English is more important } \\
\text { than studying grammar }\end{array}$ & 11 & 8,2 & 26 & 24,7 & 30,1 \\
\hline Other (please specify)* & & & & & \\
\hline
\end{tabular}

This lack of awareness, or strategy training, for example, can be seen in students' reaction to the first two opposing statements referring to the multiplechoice task. Efficient test takers do not need to know the exact meaning of each option, as they should be able to identify the correct item from the distractors immediately. However, most students agree that they need to know the meaning of all options to decide which one is correct. Another evidence of poor strategy awareness is that only $13,7 \%$ of all students read the gapped text first and then do the task. Sentence transformation is not difficult for the majority $(32,9 \%)$ of the students, which might mean that students spend a lot of time practising this type of task. Most respondents seem to believe that exposure to language through listening and reading is more important that studying grammar rules and vocabulary in isolation. The role of exposure and extended practice finds further support in a student's remark that speaking is the most important part of any language: 'In fact I didn't even know Bulgarian well (we used to talk in Turkish before) when first I went to school in town. Taking your time around a company that speaks the language is the best way to learn it."

Surprisingly, the majority of the students do not consider writing the most difficult part of the exam and they think they know how to organize their ideas in written form (see table 5): 
Table 6. Students' perceived difficulties in writing in \%

\begin{tabular}{|l|l|l|l|l|l|}
\hline Writing & $\begin{array}{l}\text { Don't } \\
\text { agree }\end{array}$ & $\begin{array}{l}\text { Somewhat } \\
\text { agree }\end{array}$ & $\begin{array}{l}\text { Neither } \\
\text { agree nor } \\
\text { disagree }\end{array}$ & Agree & $\begin{array}{l}\text { Strongly } \\
\text { agree }\end{array}$ \\
\hline $\begin{array}{l}\text { Writing is the most difficult } \\
\text { part of the exam }\end{array}$ & 31,5 & 21,9 & 21,9 & 12,3 & 12,3 \\
\hline $\begin{array}{l}\text { I'm very tired by the time I } \\
\text { have to do the writing part }\end{array}$ & 21,9 & 25 & 28,8 & 15,1 & 13,7 \\
\hline $\begin{array}{l}\text { I don't like writing in Bul- } \\
\text { garian }\end{array}$ & 32,9 & 9,6 & 26 & 6,8 & 24,7 \\
\hline $\begin{array}{l}\text { We don't do much writing } \\
\text { in class }\end{array}$ & 23,3 & 21,9 & 28,8 & 16,4 & 9,6 \\
\hline $\begin{array}{l}\text { I don't have many ideas } \\
\text { about the topic }\end{array}$ & 13,7 & 30,1 & 20,8 & 16,4 & 11 \\
\hline $\begin{array}{l}\text { I don't know how to orga- } \\
\text { nize my ideas }\end{array}$ & 35,6 & 21,9 & 19,2 & 11 & 12,3 \\
\hline $\begin{array}{l}\text { I always plan and make } \\
\text { notes before writing }\end{array}$ & 37 & 20,5 & 15,1 & 15,1 & 12,3 \\
\hline $\begin{array}{l}\text { I am not sure how to express } \\
\text { myself in English }\end{array}$ & 38,4 & 26 & 15,1 & 16,4 & 4,1 \\
\hline $\begin{array}{l}\text { When I write I use simpler } \\
\text { language }\end{array}$ & 9,6 & 20,5 & 32,9 & 21,9 & 15,1 \\
\hline $\begin{array}{l}\text { I always check and correct } \\
\text { my final draft }\end{array}$ & 5,5 & 15,1 & 21,9 & 27,4 & 30,1 \\
\hline $\begin{array}{l}\text { My teacher gives me feed- } \\
\text { back on writing }\end{array}$ & 1,4 & 6,8 & 5,5 & 16,4 & 69,9 \\
\hline $\begin{array}{l}\text { My teacher mainly corrects } \\
\text { my mistakes }\end{array}$ & 2,7 & 6,8 & 13,7 & 31,5 & 45,2 \\
\hline $\begin{array}{l}\text { I am familiar with the as- } \\
\text { sessment criteria }\end{array}$ & 5,5 & 2,7 & 31,5 & 41,1 & 19,2 \\
\hline Other (please specify)* & & & & & \\
\hline
\end{tabular}

The ambivalent reactions to the statements related to tiredness (writing is the last part of the exam), not liking writing in general, insufficient writing in class, and lack of ideas, eliminate them as potential sources of difficulties for students. A disturbing finding is that more than half of the students do not plan or make notes before writing. A high percentage of students $(38,4 \%)$ do not seem to have difficulty in expressing themselves in English, but agree that they tend to use simpler language. Resorting to simpler language is one of the main problems all students experience in the productive skills, especially in writing. A positive fact is that most respondents always check and correct their final drafts. Almost $70 \%$ state that they receive feedback on writing from their teachers, although this feedback seems to be reduced to mere correction of mistakes. It is worrying that about $40 \%$ of students are not familiar or not sure about the assessment criteria for writing. This suggests that they cannot practise self- or peer-assessment effectively in their work, but have to rely on the teachers' assessment instead. 


\section{Conclusion and implications}

The results of the survey show that students chose the maturity exam in English for a variety of reasons, among which its perceived easiness, compared with other school subjects, and students' good results in the subject. These arguments were strengthened by students' familiarity with the format, intensive study and consistent practice in the exam format. Not necessarily intending to continue their studies abroad, students see the exam as a relatively cheap and safe way to test their language level. A worrying fact is that a large number of test takers are not familiar with the assessment criteria, which makes them dependent on outer assessors. A possible reason for this might be that there is no official information about the format and the assessment criteria for each exam section on the website of the Ministry of Education. However, 97,2\% of the respondents took the decision to sit the exam themselves, and only a small number sought the advice of teachers, parents or students who had already taken the exam.

Respondents do not seem to have problems understanding instructions, finishing within time limit, remaining focused throughout the exam and coping with exam-related stress. Having in mind the ambiguous instructions for the listening part in the maturity exam, it is not clear if the students are aware of this ambiguity or not.

Students' self-evaluation in the exam areas showed that the difference between good, very good and excellent is most pronounced in the Use of English and less obvious in the areas of reading and listening, in which the percentage of those who think they are excellent is the highest. The main problems in the listening are related to the need to retain long stretches of information in short term memory, without being allowed to mark the correct answers during listening. In both listening and reading, the option 'no information in the text' causes confusion. Survey data about reading point to a lack of appropriate strategy training at school, and of students' lack of awareness of what they actually do in reading tasks. Two trends drew our attention in the Use of English part. The first one is students' uncertainty about the nature of difficulties, and the other one - poor strategy awareness. Respondents' high self-esteem in writing contradicts some common malpractices, such as not planning or checking final drafts. Feedback on writing in students' preparation seems to be limited to correction of mistakes, and students appear to be incapable of effective self- or peer-assessment, which makes them dependent entirely on their teachers' help.

The main implications for teaching could be summarized as need for constant diagnosing of difficulties, and empowering students through consistent strategy training.

Further research of teachers' attitudes and reflections on the exam and students' performance is needed in order to achieve a more comprehensive picture of 
the issues related to the maturity exam. Moreover, teachers', students' and researchers' opinions should be taken into consideration by the officials responsible for preparing the exam and evaluating its quality.

\section{References:}

Alderson, J. (1984). Reading in a foreign language: A reading problem or a language problem? In J. C. Alderson \& A. H. Urquhart (Eds.). Reading in a foreign language (pp. 1-24). London: Longman.

Alderson, C. (2000). Assessing Reading. Cambridge: Cambridge University Press.

Bachman, L. F. (2007). What is the construct? The dialectic of abilities and contexts in defining constructs in language assessment. In J. Fox, M. Wesche \& D. Bayliss (Eds.) What are we measuring? Language testing resconsidered. (pp. 41-72). Ottawa: University of Ottawa Press.

Bachman, L. F. (2010). International Encyclopedia of Education, vol. 4, (pp. 140-147).

Bachman, L. F., \& Palmer, A. S. (1996). Language testing in practice. Oxford: Oxford University Press.

Berent, G. P., Kelly, R. R., Porter, J. E., \& Fonzi, J. (2008). Deaf learners' knowledge of English universal quantifiers. Language Learning, 58(2), 401437.

Bernhardt, E. (1991). A psycholinguistic perspective on second language literacy (pp.31-44). In J. H. Hulstijn \& J. F. Matter (Eds.). Reading in two languages. AILA Review, vol.8.

Buck, G. (2001). Assessing listening. Cambridge: Cambridge University Press.

Birch, B. (2006). English L2 reading: Getting to the bottom (2nd edn.). Mahwah, NJ: Lawrence Erlbaum Associates.

Chalhoub-Deville, M. (2003). Second language interaction: Current perspectives and future trends. Language Testing, 20(4), 369-383.

Chapelle, C. (1998). Construct definition and validity inquiry in SLA research. In L. F. Bachman \& A. D. Cohen (eds.). Interfaces between second language acquisition and language testing research (pp. 32-70). New York: Cambridge University Press.

Cronbach, L. J. (1961). Essentials of psychological testing ( $2^{\text {nd }}$ edn.). New York and London: Harper \& Row and John Weatherhill, Inc.

Cutler, A. (2001). Listening to a second language through the ears of a first. Interpreting, 5, 1-23. 
Cutler, A., \& Clifton, Jr, C. (1999). Comprehending spoken language: A blueprint of the listener. In C. M. Brown \& P. Hagoort (Eds.). The neurocognition of language (pp. 123-166). Oxford: Oxford University Press.

Eskey, D. E. (2005). Reading in a second language. In E. Hinkel (Ed.), Handbook of research in second language teaching and learning. (pp. 563580). Mahwah, NJ: Lawrence Erlbaum Associates.

Fulcher, G. (2003). Testing second language speaking. London: Pearson Longman.

Gerova, G. (2019). Metakognitsiite v obuchenieto na studentite po chuzhd ezik. Shumen: Konstantin Preslavsky Publishing House.

Graham, S., \& Macaro, E. (2008). Strategy instruction in listening for lowerintermediate learners of French. Language Learning, 58, 747-783.

Harmer, J. (2001). The Practice of English Language Teaching ( $3^{\text {rd }}$ edn). New York; Longman.

Harrington, M. (2006). The lexical decision task as a measure of L2 proficiency. EUROSLA Yearbook, 6(1), 147-168.

Hidri, S. (2020). New challenges in language assessment. In S. Hidri (Ed.). Changing Language Assessment. New dimensions, new challenges (pp. 3-22). Switzerland: Palgrave Macmillan, Cham.

Hinkel, E. (2010). Integrating the four skills: Current and historical perspectives. In R. B. Kaplan (Ed.). The Oxford handbook of applied linguistics $\left(2^{\text {nd }}\right.$ edn.). (pp. 110-125).

Hinkel, E. (2011). What research on second language writing tells us and what it doesn't. In E. Hinkel (Ed.). Handbook of Research in Second Language Teaching and Learning. Vol.II (pp. 523-538). York \& London: Routledge.

Hulstijn, J. H. (2003). Connectionist models of language processing and the training of listening skills with the aid of multimedia software. Computer Assisted Language Learning, 16, 413-425.

Ivanova, I. (2020) Feedback or evaluation: Teacher-trainees' preferences for explicit evaluation in post-lesson discussions. In S. Hidri (Ed.) Changing Language Assessment. New Dimensions, New Challenges (pp. 197-222). Switzerland: Palgrave Macmillan, Cham.

Krashen, S. (1993). The power of reading ( $1^{\text {st }}$ edn). Libraries Unlimited, Englewood, CO.

Markova, Z. (2020). Naglasi na badeshtite uchiteli po angliyski ezik kam samootsenyavaneto. Orbis Linguarum, 18(2), 64-72.

McNamara, T. F. (1996). Measuring second language performance. London: Longman. 
Messick, S. (1989). Validity. In R. L. Linn (Ed.). Educational measurement (3rd ed.). (pp. 13-103). New York/ London: American Council on Education/ Macmillan.

O’Sullivan, B. (2011). Language Testing. In J. Simpson (Ed.), Routledge handbook of applied linguistics (pp. 259-273). Oxford: Routledge.

Schoonen, B. (2011). How language ability is assessed. In E. Hinkel (ed.). Handbook of research in second language teaching and learning (pp. 701716). Vol. II.

Sherman, J. (1997). The effect of question preview in listening comprehension tests. Language Testing, 14(2), 185-213.

Stanovich, K. (1991). Word recognition: Changing perspectives. In R. Barr, M. Kamil, P. Mosenthal \& P. Pearson (Eds.). Handbook of reading research. Vol. 2 (pp. 418-452). New York: Longman.

Ur, P. (1996). A course in language teaching. Cambridge: Cambridge University Press.

Vandergrift, L. (2003). Orchestrating strategy use: Toward a model of the skilled second language listener. Language Learning, 53, 463-496.

Vandergrift, L. (2005). Relationships among motivation orientations, metacognitive awareness and proficiency in L2 listening. Applied Linguistics, 26, 70-89.

Vandergrift, L. (2011). Second language listening: presage, process, product and pedagogy. In E. Hinkel (ed.). Handbook of research in second language teaching and learning. Vol. 2. (pp. 455-471). New York and London: Routledge.

Webb, S. (2008). Receptive and productive vocabulary sizes of L2 learners. Studies in Second Language Acquisition, 30(1), 79-95.

Weigle, S. C. (2002). Assessing writing. Cambridge: Cambridge University Press.

Zimmerman, B. J., \& Schunk, D. H. (2001). Self-regulated learning and academic achievement. Mahwah, NJ: Erlbaum.

\section{Internet sources:}

Dvama ot trima uchenitsi chetat samo ako tryabva. (2015, January 8). Retrieved November 03, 2020, from http://btvnovinite.bg/article/bulgaria/obshtestvo/ dvama-ot-trima-uchenici-chetat-samo-ako-trjabva.html.

Garigov, M. (2017). Matura po chuzhd ezik. Retrieved November 03, 2020, from http://www.zamatura.eu/page/matura-chujd-ezik-programa. 
Georgieva, S. (2020, June 02). MON publikuva vaprosite I otgovorite na maturata. Retrieved November 03, 2020, from https://www.segabg.com/hot/ category-education/mon-publikuva-vuprosite-i-otgovorite-na-maturata.

Sadkova, Y. (2011, August 31). Agonizira li obrazovatelnata ni sistema? Retrieved November 03, 2020, from http://www.hermesbg.org/tr/nova-biblioteka/book30/995-agonizira-li-obrazovatelnata-ni-sistema.html 